\section{Trehalose Delays Senescence in Cut Gladiolus Spikes}

\author{
Mayuko Otsubo and Mari Iwaya-Inoue ${ }^{1}$ \\ Laboratory of Horticultural Sciences, Department of Plant Resource, Faculty \\ of Agriculture, Graduate School, Kyushu University, Ropponmatsu, Fukuoka \\ 810-8560, Japan
}

Additional index words. cut flower, cycloheximide, Gladiolus $\times$ grandiflora, iodoacetic acid, sugars, tetranitro blue tetrazolium (TNBT), vase-life, water content, wilting

\begin{abstract}
Florets of cut gladiolus (Gladiolus $\times$ grandiflora hort. cv. Fujinoyuki) spikes kept at $25{ }^{\circ} \mathrm{C}$ under $14 \mathrm{~h}$ light/10 h dark condition showed severe wilting 4 days after flower opening. Treatment with $0.1 \mathrm{~m}$ trehalose prolonged vase-life 2 days, whereas inhibitors and other sugars had no effect. The upper florets also opened properly in trehalose-treated spikes, but not in cycloheximide-treated ones. After 4 days, the first florets of trehalose-treated spikes maintained water content more effectively than did controls or spikes treated with other sugars. The parenchyma adjacent to vascular bundles in the petals of trehalose-treated spikes maintained viability for $\mathbf{4}$ days. These results suggest that trehalose preserves cell viability in gladiolus spikes, thereby enhancing water uptake into petal tissues.
\end{abstract}

Trehalose, a disaccharide consisting of two $\alpha-[1,1]$ linked glucose units, occurs in bacteria, yeast, fungi, algae, insects, and various invertebrates (Elbein, 1974). In angiosperms, high concentrations of trehalose have been demonstrated only in resurrection plants such as Myrothamnus flabellifolius Welw. (Bianchi et al., 1993; Drennan et al., 1993). Introduction of a gene for synthesis of trehalose in tobacco (Nicotiana tabacum L.) plants greatly increased ability to survive drought (Goddijn et al., 1997; Holmström et al., 1996). Further, when detached leaves of transgenic tobacco plants were air-dried to test their viability, they lost water more slowly than did those of wild-type plants (Holmström et al., 1996). Thus, trehalose accumulation in plant cells appears to improve water retention. It also appears to protect membranes and enzymes from various stresses (Crowe et al., 1984; Hottinger et al., 1994; Lee et al., 1989; Müller et al., 1995), although its mechanism of action remains little understood. In petals of cut flowers undergoing senescence, protein content falls (Lay-Yee et al., 1992), protease activity increases (Valpuesta et al., 1995), lipid fluidity in the membranes declines (Itzhaki et al., 1990), and respiration

Received for publication 9 Aug. 1999. Accepted for publication 14 Jan. 2000. This work was supported in part by a Grant-in-Aid (No. 11460016) for Scientific Research from the Ministry of Education, Science, Sports, and Culture of Japan to M.I.I. We thank M. Sakurai of the Tokyo Institute of Technology and Hayashibara Co., for the gift of trehalose, and N. Tamura of Fukuoka Women's Univ. for reading the original manuscript. The cost of publishing this paper was defrayed in part by the payment of page charges. Under postal regulations, this paper therefore must be hereby marked advertisement solely to indicate this fact.

${ }^{1}$ To whom requests for reprints should be addressed. E-mail address: marircb@mbox.nc.kyushu-u.ac.jp rate increases (Bieleski and Reid, 1992). Therefore, we hypothesize that trehalose may prevent water loss in cut flowers by protecting enzymes and membranes.

Senescence is delayed by sucrose in many cut flowers such as the carnation (Dianthus caryophyllus L.) (Koyama and Uda, 1994) and rose (Rosa hybrida L.) (Kuiper et al., 1995). In cut gladiolus spikes, sucrose slightly increased spike quality (Bravdo et al., 1974; Kofranek and Halevy, 1976). Sucrose prolongs the vase life of cut flowers of sweet pea (Lathyrus odoratus L.), by a mechanism related to the inhibition of ethylene production (Ichimura and Hiraya, 1999). However, inhibitors of ethylene action such as silver thiosulfate (STS) do not affect the life of cut gladiolus flowers (Serek et al., 1994; Yamane et al., 1993), suggesting that sucrose does not act via ethylene inhibition in this species. Treatment of detached florets with cycloheximide (CHI), an inhibitor of protein synthesis on the $60 \mathrm{~S}$ ribosome, prolonged vase-life two-fold in their opening stage, while its addition at the bud stage inhibited their growth completely (Jones et al., 1994; Yamane and Ogata, 1995). Treatment of detached gladiolus florets with the free radical scavengers sodium benzoate and n-propyl gallate slightly delayed wilting (Yamane et al., 1999). In this study, we demonstrate that $0.1 \mathrm{~m}$ trehalose remarkably suppresses water loss and enhances viability in petals, but slightly hastens wilting in bract of cut gladiolus spikes.

\section{Materials and Methods}

Plant materials and treatment. Spikes of gladiolus (Gladiolus $\times$ grandiflora hort. cv. Fujinoyuki), grown in a field at Kyushu Univ., were harvested from July to Sept. 1998 at the early opening stage of the first florets in the spikes, then used immediately. Cut gladiolus spikes ( $50 \pm 5 \mathrm{~cm}$ long) with $8-10$ florets were recut under distilled water $15 \mathrm{~cm}$ beneath the first floret, then transferred to test tubes containing $10 \mathrm{~mL}$ of distilled water (control) or solutions of $0.1 \mathrm{~mm} \mathrm{CHI,} 0.2 \mathrm{~mm}$ iodoacetic acid, or $0.1 \mathrm{~mm}$ phenylmethylsulfonyl fluoride (PMSF) as inhibitors, $5 \mu \mathrm{M}$ fusicoccin as a fungal toxin, and $0.1 \mathrm{M}$ sugars, such as glucose, maltose, trehalose, and sucrose, respectively. They were kept at $25 \pm 1{ }^{\circ} \mathrm{C}$ and $\approx 60 \%$ relative humidity $(\mathrm{RH})$, under $14 \mathrm{~h}$ of illumination at $100 \mu \mathrm{mol} \cdot \mathrm{m}^{-2} \cdot \mathrm{s}^{-1}$, and evaluated daily.

Wilting score. The state of senescence for each floret was evaluated daily based on the degree of both wilting and browning. Life stages of a floret were defined by the following six scores: $1=$ half-opened; 2 = fully opened; $3=$ slightly wilted at the petal edge; $4=$ slightly wilted whole petal; $5=$ severely wilted whole petal; and $6=$ severely wilted and browned whole petal. Typical examples of these stages are presented in Fig. 1.

Measurement of water content. Fresh and dry weights of the first florets were recorded daily and the subtending pair of bracts on eight gladiolus spikes were harvested each day. Dry matter was measured after drying in an oven at $90^{\circ} \mathrm{C}$ for $20 \mathrm{~h}$.

TNBT staining. Daily, the edges of fresh petals from the first florets on five spikes were cut into pieces $(5 \times 5 \mathrm{~mm})$ and incubated overnight at $25^{\circ} \mathrm{C}$ in the dark in $50 \mu \mathrm{M}$ phosphate buffer ( $\mathrm{pH} 7.5$ ) containing $0.1 \%$ tetranitro blue tetrazolium (TNBT). Formation of a purplish-black formazan, accompanied by reduction of the tetrazolium salts by active dehydrogenase (Rosa and Tsou, 1961), was observed with a light microscope (Axiphot, Carl Zeiss, Tokyo).

\section{Results}

Senescence symptoms. A floret of gladiolus consists of three outer petals and three inner ones (Fig. 1). The first and second florets were fully opened $1 \mathrm{~d}$ after harvest, and about two additional florets opened fully each additional day. The first floret wilted and the petal color changed from white to brown after $4 \mathrm{~d}$ in distilled water (Fig. 2). The senescence process of spikes grown in the field was similar to that of the cut spikes. We investigated the effects of various types of inhibitors on the senescence process (Fig. $2 \mathrm{~A}$ ). The rate of senescence was not significantly affected by $0.2 \mathrm{~mm}$ iodoacetic acid or $0.1 \mathrm{~mm}$ PMSF, inhibitors of cysteine- or serine-protease, respectively (Celikel et al., 1995) (Fig. 2A). The phytotoxin fusicoccin $(5 \mu \mathrm{M})$, which increases stomatal opening by activating the plasma membrane $\mathrm{H}^{+}$-ATPase (Marre, 1979), accelerated wilting. In contrast, the protein biosynthesis inhibitor, $\mathrm{CHI}$ $(0.1 \mu \mathrm{M})$ delayed senescence of the first floret, but completely inhibited petal expansion of the $3 \mathrm{rd}$, 4th, and 5 th florets on the spikes (Fig. 3).

We also studied the effects of $0.1 \mathrm{M}$ monoand disaccharides on senescence of the cut spikes (Fig. 2B). Maltose did not affect the longevity of the cut flower, nor did sucrose or 


\section{Postharvest Biology \& Technology}

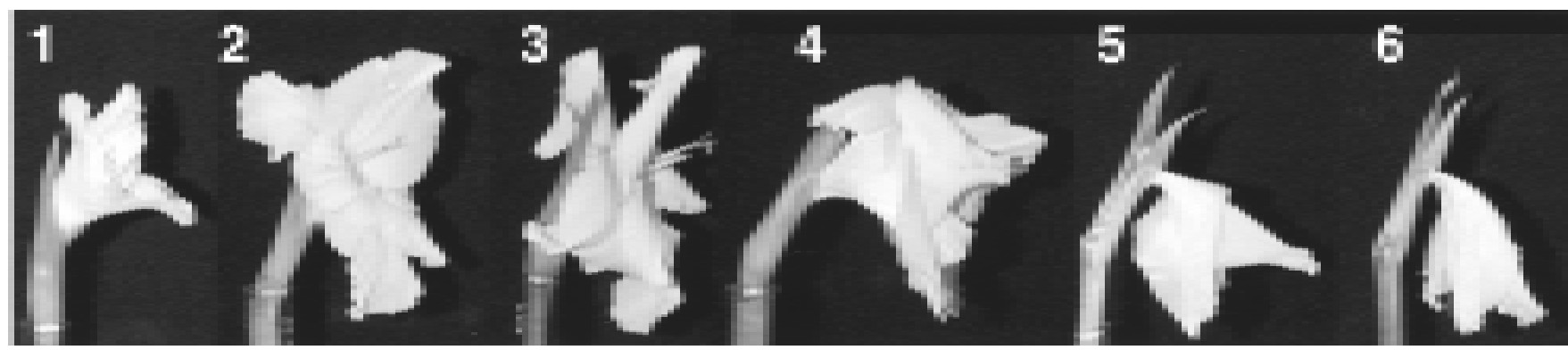

Fig. 1. Scores of floret senescence in gladiolus spikes: (1) half-opened, (2) fully opened, (3) slightly wilted petal edge, (4) slightly wilted whole petal, (5) severely wilted whole petal, (6) severely wilted and browned whole petal.

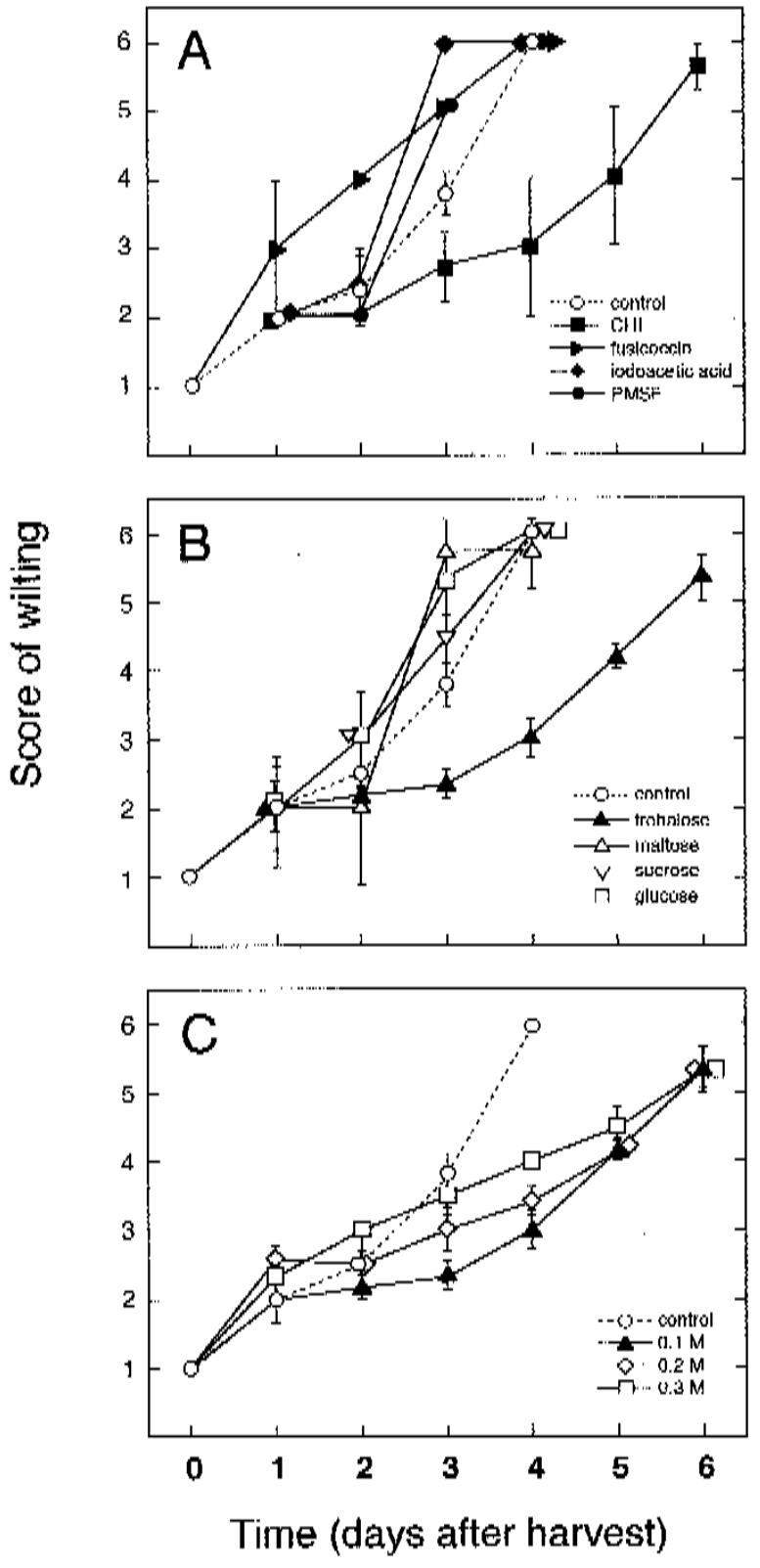

Fig. 2. Effects of chemicals $(\mathbf{A})$ and sugars $[(\mathbf{B})$ and $(\mathbf{C})]$ on wilting of first florets of cut gladiolus spikes. Spikes were kept in: (A) control (distilled water) $(\mathrm{O})$; $0.1 \mathrm{~mm}$ CHI (ם); $0.2 \mathrm{~mm}$ iodoacetic acid $(\diamond) ; 0.1 \mathrm{~mm} \operatorname{PMSF}(\bullet) ; 5 \mu \mathrm{M}$ fusicoccin $(\square)$ : (B) control (distilled water) $(\bigcirc)$; trehalose $(\mathbf{\Delta})$; maltose $(\Delta)$; sucrose $(\nabla)$; glucose $(\square)$ : and $(\mathbf{C})$ distilled water $(0 \mathrm{~m})(\bigcirc) ; 0.1 \mathrm{~m}(\mathrm{~s}) ; 0.2 \mathrm{~m}$

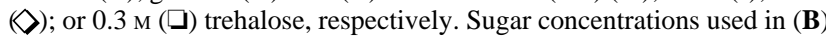
were 0.1 м. Flower wilting was scored as shown in Fig. 1. Symbols represent mean \pm SE $(n=6 \sim 10)$. SE bars are not visible when they are smaller than symbols.

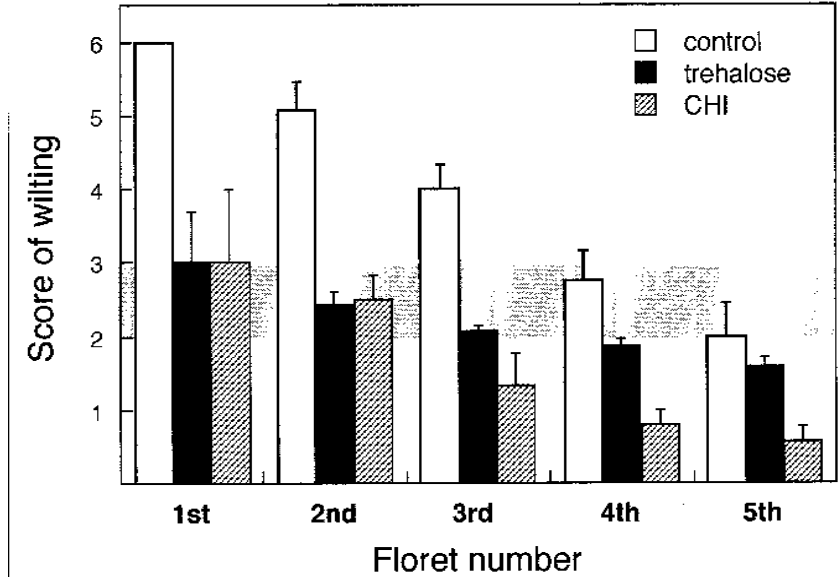

Fig. 3. Effects of $0.1 \mathrm{~m}$ trehalose and $0.1 \mathrm{~mm} \mathrm{CHI}$ on wilting of the $1 \mathrm{st}$ to 5 th florets (lowest and oldest floret is the 1st) of cut gladiolus spikes after $4 \mathrm{~d}$. Flower wilting was scored as shown in Fig. 1. Symbols represent mean \pm SE $(\mathrm{n}=10)$.

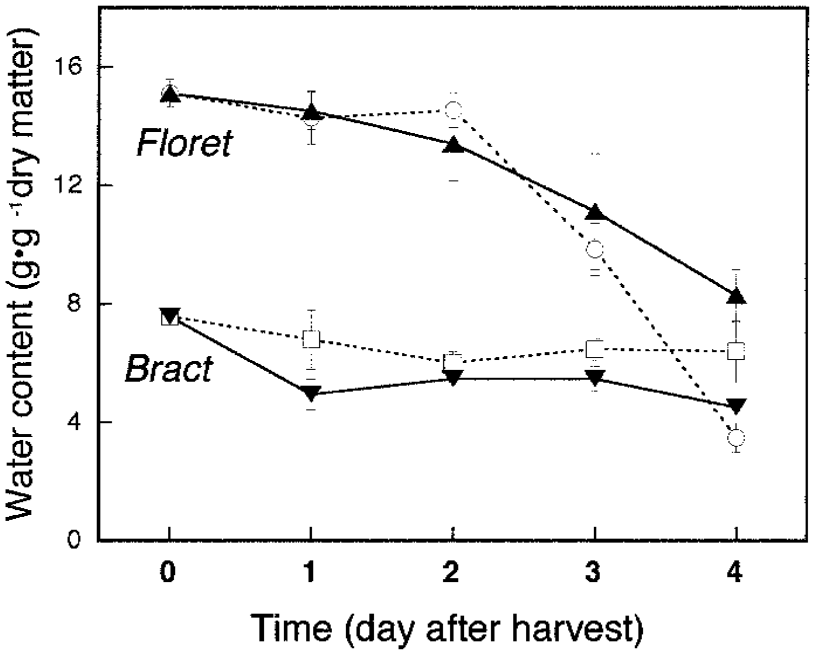

Fig. 4. Effects of $0.1 \mathrm{~m}$ trehalose on water content of the first florets and bracts of cut gladiolus spikes. Relative water contents are expressed as the ratio of water to dry weight. Control (distilled water) $(\bigcirc), 0.1 \mathrm{~m}$ trehalose $(\boldsymbol{\Delta})$ in florets, control $(\square)$ and $0.1 \mathrm{M}$ trehalose $(\boldsymbol{\nabla})$ in bracts. Symbols represent mean $\pm \mathrm{SE}(\mathrm{n}=8)$. SE bars are not visible when they are smaller than symbols. 
glucose. However, trehalose kept the senescence stage at about a score of 3 for $4 \mathrm{~d}$ (Fig. 2B). In trehalose-treated spikes, the upper florets were well developed and without aberration. After $4 \mathrm{~d}$, trehalose-treated spikes had a higher number of pristine florets with scores between 2 and 3 than did control or CHI-treated spikes (Fig. 3). Treatment with $0.1 \mathrm{~m}$ trehalose kept florets fresh for a longer time than did treatment with $0.2 \mathrm{M}$ and $0.3 \mathrm{M}$ trehalose (Fig. 2C). Therefore, we used $0.1 \mathrm{~m}$ trehalose in subsequent experiments.

Water content. We studied the relative water content of the first floret in order to evaluate wilting quantitatively. Beginning $3 \mathrm{~d}$ after harvest, there were significant differences in the wilting scores among the sugar treatments. At $3 \mathrm{~d}$, the water contents of first florets were

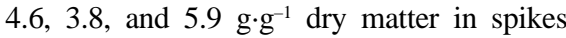
treated with maltose, sucrose, and glucose at $0.1 \mathrm{M}$, respectively, all of which were much lower than the water content of the control. However, the water content of the first floret of trehalosetreated spikes was $11.1 \mathrm{~g} \cdot \mathrm{g}^{-1}$ dry matter, about twice that of the florets treated with other sugars.

Water content of florets remained relatively constant for the first $2 \mathrm{~d}$, but after that decreased faster in control than in trehalose-treated spikes thereafter (Fig. 4). Changes in dry weights of the florets showed a similar tendency, but water content of the control floret decreased to $<50 \%$ of that in the trehalose-treated floret by $4 \mathrm{~d}$ after harvest. These results suggest that trehalose specifically enhanced water uptake into petals. However, changes in relative water contents of the bracts in the trehalose-treated spikes were lower than those in the control spikes, resulting from a dry matter increase in the bracts of the trehalose-treated spikes (data not shown).

TNBT staining. When tetrazolium salts such as TNBT are reduced by endogenous dehydrogenase, a purplish-black formazan is observed. Staining requires dehydrogenase activity, indicating tissue viability (Rosa and Tsou, 1961). Petals of the spikes treated with $0.1 \mathrm{M}$ trehalose or distilled water were well-stained $1 \mathrm{~d}$ after treatment, particularly the parenchyma cells adjacent to the vascular bundles. After $4 \mathrm{~d}$, the tissue in trehalose-treated petals was still wellstained, but no staining was observed in the control (Fig. 5). These results indicate that trehalose preserved the tissue viability of the petal for up to $4 \mathrm{~d}$.

\section{Discussion}

Of the sugars tested, only trehalose was effective in delaying gladiolus floret senescence (Fig. 2B). Water content of the first floret of the trehalose-treated spikes was about twice that of the florets treated with the other three sugars. In

\section{Control}
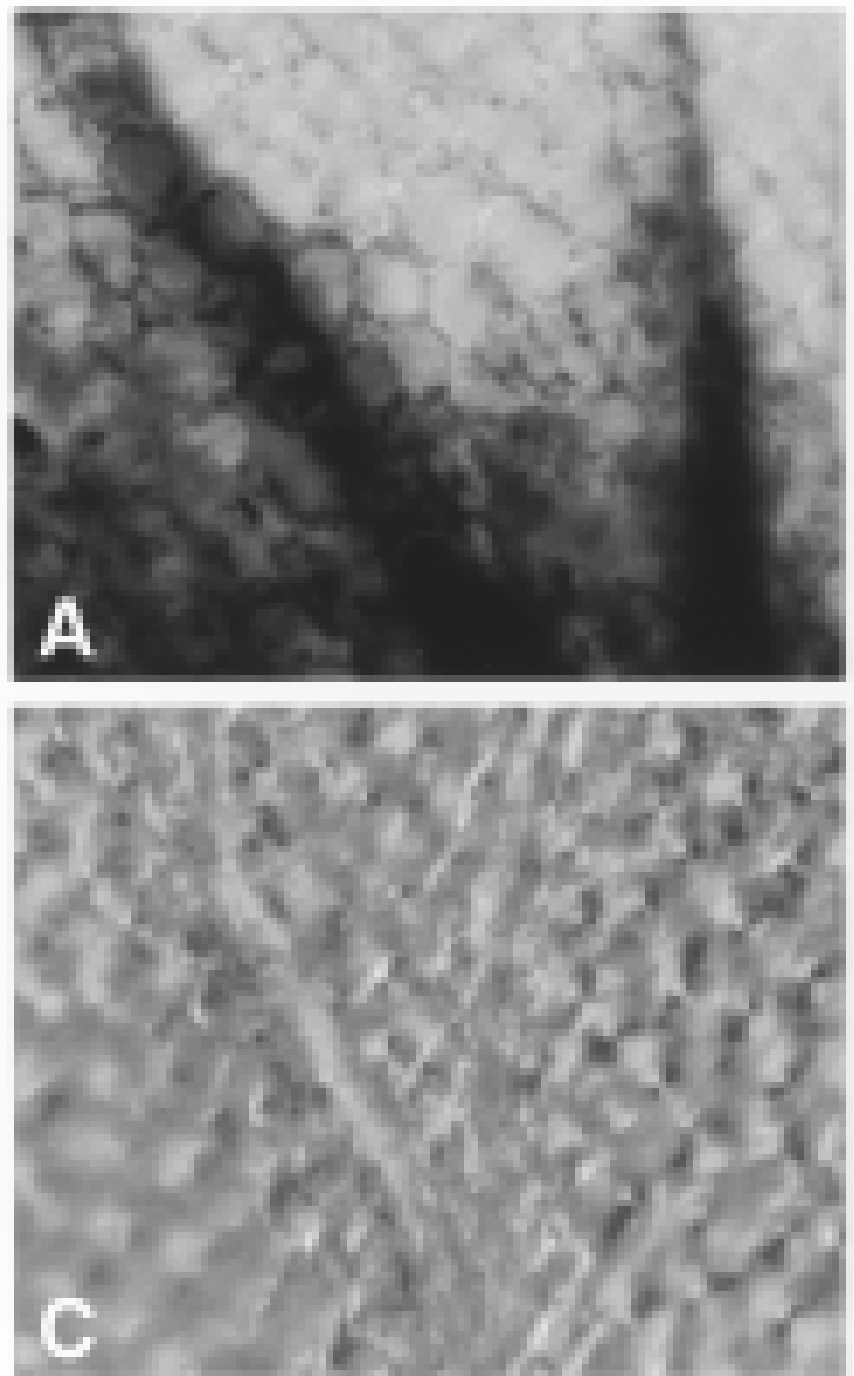

\section{Trehalose}
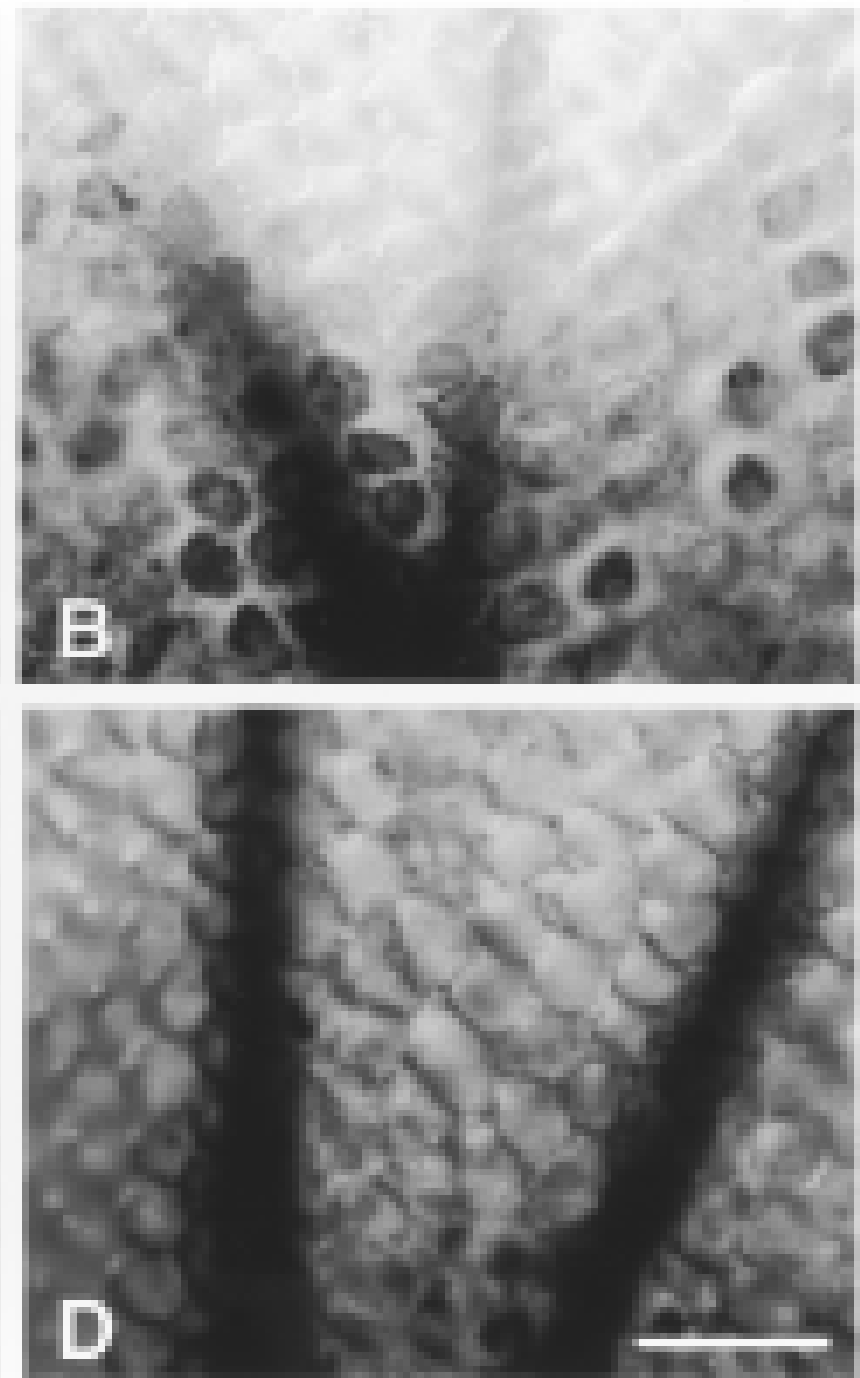

Fig. 5. Photomicrographs of petal edges in the first florets of cut gladiolus spikes. (A) and (B) represent the control and trehalose-treated petals at $1 \mathrm{~d}$, respectively, and $(\mathbf{C})$ and $(\mathbf{D})$ represent those at $4 \mathrm{~d}$. The staining was performed as described in Materials and Methods. Photograph represents one of five samples. $\operatorname{Bar}=50 \mu \mathrm{M}$. 
trehalose-treated spikes, large increases in water and dry matter content occurred on the first day, and these spikes retained more water than did the control over the 4-d examination period. This finding suggests that trehalose maintains a higher degree of turgor in the petals than do the other sugars. Additionally, TNBT staining, which reflects tissue viability (Iwaya-Inoue et al., 1998; Kano et al., 1993; Rosa and Tsou, 1961), indicated that the parenchyma tissue adjacent to the vascular bundles of the florets was alive in the petals from the trehalose-treated spikes, but not in the control (Fig. 5). Since the relative water content of the first floret in the trehalosetreated spike was greater than that of the control at $4 \mathrm{~d}$ (Fig. 4), we conclude that the transfer of water from vessels to the petal parenchyma occurs normally in the trehalose-treated spikes.

Most higher plants do not accumulate trehalose, but the desiccation-tolerant angiosperm Myrothamnus flabellifolius accumulates high levels of both trehalose and sucrose (Bianch et al., 1993; Drennan et al., 1993). Detached leaves of tobacco plants, in which trehalose accumulation was induced by introduction of a gene encoding trehalose-6-phosphate synthase, showed improved water retention under drought stress conditions (Holmström et al., 1996). Further, introduction of two genes encoding trehalose-synthesizing enzymes into tobacco plants increased growth rates and photosynthetic efficiency when water supply was limited (Pilon-Smits et al., 1998). Bakaltcheva et al. (1994) suggested that trehalose protects biological membranes, such as the plasma membrane, the tonoplast, and the chloroplast envelope, under drought stress. In contrast, we found that the edge of bracts in the trehalose-treated gladiolus spikes were dry (Fig. 4), and bracts appeared to have suffered some damage over the course of the $4 \mathrm{~d}$. Growth of transgenic tobacco was inferior to that of the wild-type when plants were grown under optimal conditions (Holmström et al., 1996; Pilon-Smits et al., 1998). Trehalose feeding also suppressed growth and cell wall synthesis in vitro of shoot tips of Cuscuta reflexa Roxb. (Veluthambi et al., 1981, 1982). Although water loss in gladiolus bracts has only a slight influence on the appearance of the spike, we need to elucidate why trehalose induces desiccation of the bracts in cut flowers.

As previously noted, gladiolus flowers were found to be ethylene-insensitive (Serek et al., 1994; Yamane et al., 1993). Treatment with $\mathrm{CHI}$, an inhibitor of protein synthesis, was effective in extending the vase-life of half- and fully opened gladiolus florets, although its application to flowers at immature stages inhibited the opening of buds (Jones et al., 1994; Yamane and Ogata, 1995). A similar tendency was observed in whole spikes in our series; the vase-life of the first floret was improved (Fig. 2A), but the opening and development of the immature florets were severely inhibited (Fig. 3), and pigments accumulated. These results indicate that $\mathrm{CHI}$ is not suitable for commercial use to delay the senescence of gladiolus spikes. The protease inhibitors io- doacetic acid and PMSF, and the stomatal closure inhibitor fusicoccin, accelerated wilting of the petal. Thus, only trehalose was effective in maintaining the first floret over the course of 4 $\mathrm{d}$, while also permitting opening of the fifth floret.

We conclude that $0.1 \mathrm{~m}$ trehalose suppressed water loss and enhanced viability in petals, although a slight wilting in the bracts of cut gladiolus spikes was simultaneously observed. In order to clarify this mechanism of cut flower senescence, further studies including investigation into sugar components, changes in proteins, and physical states of water, are necessary.

\section{Literature Cited}

Bakaltcheva, I., W. Williams, J. Schmitt, and D. Hincha. 1994. The solute permeability of thylakoid membranes is reduced by low concentrations of trehalose as a cosolute. Biochem. Biophys. Acta 1189:38-44.

Bianchi, G., A. Gamba, R. Limiroli, N. Pozzi, R. Elster, F. Salamini, and D. Bartels. 1993 The unusual sugar composition in leaves of the resurrection plant Myrothamnus flabellifolia. Physiol. Plant. 87: 223-226.

Bieleski, R.L. and M.S. Reid. 1992. Physiological changes accompanying senescence in the ephemeral daylily flower. Plant Physiol. 98:1042-1049.

Bravdo, B., S. Mayak, and Y. Gravrieli. 1974 Sucrose and water uptake from concentrated sucrose solution by gladiolus shoots and effect of these treatments on floret life. Can. J. Bot. 52:1271-1281.

Celikel, F.G. and W.G. van Doorn. 1995. Solute leakage, lipid peroxidation, and protein degradation during the senescence of iris tepals. Physiol. Plant. 94:515-521.

Crowe, J., L. Crowe, and D. Chapman. 1984. Preservation of membranes in anhydrobiotic organisms: The role of trehalose. Science 223:209217.

Drennan, P.M., M.T. Smith, D. Goldsworthy, and J. van Staden. 1993. The occurrence of trehalose in the leaves of the desiccation-tolerant angiosperm Myrothamnusflabellifolius Welw.J.Plant Physiol. 142:493-496.

Elbein, A. 1974. The metabolism of $\alpha, \alpha$-trehalose. Adv. Carbohydrate Chem. Biochem. 30:227256.

Goddijn, O.J.M., T.C.Verwoerd,E. Voogd,R.W.H.H. Krutwagen, P.T.H.M. de Graaf, J. Poels, K. van Dun, A.S. Ponstein, B. Damm, and J. Pen. 1997. Inhibition of trehalase activity enhances trehalose accumulation in transgenic plants. Plant Physiol. 113:181-190.

Holmström, K.O., E. Mäntylä, B. Welin, A. Mandel, E. T.Palva, O.E. Tunnela, and J.Londesborough. 1996. Drought tolerance in tobacco. Nature 379:683-684.

Hottinger, T., C. De Virgilio, M. Hall, T. Boller, and A. Wiemken. 1994. The role of trehalose synthesis for the acquisition of thermo-tolerance in yeast. II. Physiological concentration of trehalose increases the thermal stability of proteins in vitro. Eur. J. Biochem. 219:187-193.

Ichimura, K. and T. Hiraya. 1999. Effect of thiosulfate complex (STS) in combination with sucrose on the vase life of cut sweet pea flowers. J. Jpn. Soc. Hort. Sci. 68:23-27.

Itzhaki, H., A. Borochov, and S. Mayak. 1990. Agerelated changes in petal membranes from attached and detached rose flowers. Plant Physiol. 94:1233-1236.

Iwaya-Inoue, M., K. Motooka, and G. Watanabe.
1998. Significance of low temperature requirement on dormancy breaking for tulip bulbs as estimated by ${ }^{1} \mathrm{H}-\mathrm{NMR}$. Cryobiol. Cryotechnol. 44:21-28.

Jones, R.B., M. Serek, C.-L. Kuo, and M.S. Reid. 1994. The effect of protein synthesis inhibition on petal senescence in cut bulb flowers. J. Amer. Soc. Hort. Sci. 119:1243-1247.

Kano, H., N. Ishida, H. Takagishi, K. Shirata, and M. Koizumi. 1993. Tracing effects of $\mathrm{Na}^{+}$on morphology, phosphate metabolism, and accumulated compounds of a sugar beet root by NMR Jpn. J. Crop Sci. 62:95-104.

Kofranek, A.M. and A.H. Halevy. 1976. Sucrose pulsing of gladiolus stems before storage to increase spike quality. Hortscience 11:572573.

Koyama, Y and A. Uda. 1994. Effects of temperature, light intensity and sucrose concentration on bud forcing and carnation flower quality (in Japanese with English summary). J. Jpn. Soc. Hort. Sci. 63:203-209.

Kuiper, D., S. Ribot, H.S. van Reenen, and N. Marissen. 1995. The effect of sucrose on the flower bud opening of Madelon cut roses. Scientia Hort. 60:325-336.

Lay-Yee, M., A.D. Stead, and M.S. Reid. 1992 Flower senescence in daylily (Hemerocallis). Physiol. Plant. 86:308-314.

Lee, C.W.B., S.K. Das Gupta, J. Mattai, G.G. Shipley, O.H. A-Mageed, A. Makriyannis, and R.G. Griffin. 1989. Characterization of the $L_{\lambda}$ phase in trehalose-stabilized dry membranes by solid-state NMR and X-ray diffraction. Biochemistry 28:5000-5009.

Marre, E. 1979. Fusicoccin: A tool in plant physiology. Annu. Rev. Plant Physiol. 30:273-288.

Müller, J., T. Boller, and A. Wiemken. 1995. Trehalose and trehalase in plants: Recent developments. Plant Sci. 112:1-9.

Pilon-Smits, E.A.H., N. Terry, T. Sears, H. Kim, A. Zayed, S. Hwang, K. van Dun, E. Voogd, T.C. Verwoerd, R.W.H.H. Krutwagen, and O.J.M Goddijn. 1998. Trehalose-producing transgenic tobacco plants show improved growth performance under drought stress. J. Plant Physiol. 152:525-532.

Rosa, C.G. and K.C. Tsou. 1961. Use of tetrazolium compounds in oxidative enzyme histo- and cytochemistry. Nature 192:990-991.

Serek, M., R.B. Jones, and M.S. Reid 1994. Role of ethylene in opening and senescence of gladiolus (Gladiolus sp.) flowers. J. Amer. Soc. Hort. Sci. 119:1014-1019.

Valpuesta, V., N.E. Lange, C. Guerrero, and M.S Reid. 1995. Up-regulation of cysteine protease accompanies the ethylene-insensitive senescence of daylily (Hemerocallis) flowers. Plant Mol. Biol. 28:575-582.

Veluthambi, K., S. Mahadevan, and R. Maheshwari. 1981. Trehalose toxicity in Cuscuta reflexa. Plant Physiol. 68:1369-1374.

Veluthambi, K., S. Mahadevan, and R. Maheshwari. 1982. Trehalose toxicity in Cuscuta reflexa. Plant Physiol. 70:686-688.

Yamane, K. and R. Ogata. 1995. Effects of cycloheximide on physiological parameters of gladiolus florets during growth and senescence. J. Jpn. Soc. Hort. Sci. 64:411-416.

Yamane, K. and S. Kawabata, and N. Fujishige. 1999. Changes in activities of superoxide dismutase, catalase and peroxidase during senescence of gladiolus florets. J. Jpn. Soc. Hort. Sci. 68:798-802.

Yamane, K., S. Abiru, N. Fujishige, R. Sakiyama, and R. Ogata. 1993. Export of soluble sugars and increase in membrane permeability of gladiolus florets during senescence. J. Jpn. Soc. Hort. Sci. 62:575-580 